\title{
Yield, growth and grain nitrogen response to elevated CO2 in six lentil (Lens culinaris) cultivars grown under Free Air $\mathrm{CO} 2$ Enrichment (FACE) in a semi-arid environment
}

\author{
Authors: M. Bourgault, J. Brand, S. Tausz-Posch, R.D. \\ Armstrong, G.L. O’Leary, G.J. Fitzgerald, \& M. Tausz
}

NOTICE: this is the author's version of a work that was accepted for publication in European Journal of Agronomy. Changes resulting from the publishing process, such as peer review, editing, corrections, structural formatting, and other quality control mechanisms may not be reflected in this document. Changes may have been made to this work since it was submitted for publication. A definitive version was subsequently published in European Journal of Agronomy VOL\# 87, (July 2017), DOI\# 10.1016/j.eja.2017.05.003.

Bourgault, Maryse, J. Brand, S. Tausz-Posch, R.D. Armstrong, G.L. O'Leary, G.J. Fitzgerald, and M. Tausz. "Yield, growth and grain nitrogen response to elevated CO2 in six lentil (Lens culinaris) cultivars grown under Free Air CO2 Enrichment (FACE) in a semi-arid environment." European Journal of Agronomy 87 (Juy 2017): 50-58. DOI: 10.1016/j.eja.2017.05.003.

Made available through Montana State University's ScholarWorks scholarworks.montana.edu 


\title{
Yield, growth and grain nitrogen response to elevated $\mathrm{CO}_{2}$ in six lentil (Lens culinaris) cultivars grown under Free Air $\mathrm{CO}_{2}$ Enrichment (FACE) in a semi- arid environment
}

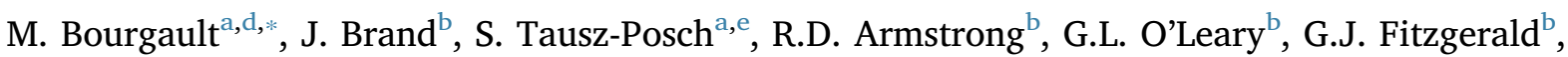 \\ M. Tausz, ${ }^{\mathrm{c}}$
}

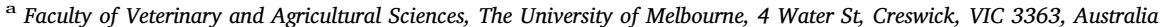

b Agriculture Victoria, Grains Innovation Park, 110 Natimuk Rd, Horsham, VIC, 3401, Australia

${ }^{c}$ Faculty of Science, The University of Melbourne, 4 Water St, Creswick, VIC, 3363, Australia

d Northern Agricultural Research Center, Montana State University, 3710 Assinniboine Rd, Havre, MT, 59501-8214, USA

e School of Biosciences, University of Birmingham, Birmingham B15 2TT, UK

${ }^{\mathrm{f}}$ Birmingham Institute of Forest Research, University of Birmingham, Birmingham B15 2TT, UK

\section{A R T I C L E I N F O}

\section{Keywords:}

Source-sink relationships

Physiological pre-breeding

Climate change adaptation

Terminal drought

\begin{abstract}
A B S T R A C T
Atmospheric $\mathrm{CO}_{2}$ concentrations $\left(\left[\mathrm{CO}_{2}\right]\right)$ are predicted to increase from current levels of about $400 \mathrm{ppm}$ to reach $550 \mathrm{ppm}$ by 2050 . The direct benefits of elevated $\left[\mathrm{CO}_{2}\right]\left(\mathrm{e}\left[\mathrm{CO}_{2}\right]\right)$ to plant growth appear to be greater under low rainfall conditions, but there are few field (Free Air $\mathrm{CO}_{2}$ Enrichment or FACE) experimental set-ups that directly address semi-arid conditions. The objectives of this study were to investigate the following research questions: 1) What are the effects of $\mathrm{e}\left[\mathrm{CO}_{2}\right]$ on the growth and grain yield of lentil (Lens culinaris) grown under semi-arid conditions under FACE? 2) Does e $\left[\mathrm{CO}_{2}\right]$ decrease grain nitrogen in lentil? and 3) Is there genotypic variability in the response to $\mathrm{e}\left[\mathrm{CO}_{2}\right]$ in lentil cultivars? Elevated $\left[\mathrm{CO}_{2}\right]$ increased yields by approximately $0.5 \mathrm{t} \mathrm{ha}^{-1}$ (relative increase ranging from 18 to 138\%) by increasing both biomass accumulation (by 32\%) and the harvest index (by up to $60 \%$ ). However, the relative response of grain yield to $\mathrm{e}\left[\mathrm{CO}_{2}\right]$ was not consistently greater under dry conditions and might depend on water availability post-flowering. Grain nitrogen concentration was significantly reduced by $\mathrm{e}\left[\mathrm{CO}_{2}\right]$ under the conditions of this experiment. No differences were found between the cultivars selected in the response to elevated $\left[\mathrm{CO}_{2}\right]$ for grain yield or any other parameters observed despite well expressed genotypic variability in many traits of interest. Biomass accumulation from flowering to maturity was considerably increased by elevated $\left[\mathrm{CO}_{2}\right]$ (a $50 \%$ increase) which suggests that the indeterminate growth habit of lentils provides vegetative sinks in addition to reproductive sinks during the grain-filling period.
\end{abstract}

\section{Introduction}

Atmospheric $\mathrm{CO}_{2}$ concentrations $\left(\left[\mathrm{CO}_{2}\right]\right)$ have been increasing from about $280 \mathrm{ppm}$ to $406 \mathrm{ppm}$ from the pre-industrial era until now (January 2017; www.co2.earth; last accessed 23 February 2017). If global greenhouse gas emissions remain at the 2010 level, then atmospheric $\mathrm{CO}_{2}$ concentrations $\left(\left[\mathrm{CO}_{2}\right]\right)$ should reach $550 \mathrm{ppm}$ by 2050 (IPCC, 2014). This increase in the substrate of photosynthesis has direct implications for plant metabolism, such as increased growth and yield, at least in C3 plants and in the absence of changes in temperature and rainfall patterns (Ainsworth and Long 2005; Ziska et al., 2012). Elevated $\left[\mathrm{CO}_{2}\right]\left(\mathrm{e}\left[\mathrm{CO}_{2}\right]\right)$ also reduces stomatal conductance, leading to higher transpiration efficiency (Leakey et al., 2009; Tausz-Posch et al., 2013) and potentially increased crop water productivity under conditions of water stress (Deryng et al., 2016; Gifford, 1979). In environments prone to severe terminal drought (where the crop progressively runs out of water with no resupply), there are however concerns that the early increases in leaf area and biomass accumulation under $\mathrm{e}\left[\mathrm{CO}_{2}\right]$ might negate the water savings from higher transpiration efficiency, potentially leading to an earlier onset of drought. This could reduce post-flowering growth and translocation of assimilates and therefore reduce the yield response to $\mathrm{e}\left[\mathrm{CO}_{2}\right]$. There are few FACE experimental set-ups that directly address this type of water stress, and experimental data to support or disprove this theory is sparse (Deryng et al., 2016).

Higher growth and grain yield are often associated with decreased 
grain quality, especially in cereals, where decreases in grain nitrogen concentration $([\mathrm{N}])$ and therefore protein concentrations, raise concerns about nutrition and product quality (Jablonski et al., 2002; Myers et al., 2014). Decreased grain $[\mathrm{N}]$ under $\mathrm{e}\left[\mathrm{CO}_{2}\right]$ is preceded by decreases in $[\mathrm{N}]$ in vegetative biomass, particularly in leaves (Leakey et al., 2009). There are several hypotheses to explain this decrease in tissue $[\mathrm{N}]$ (reviewed by Taub and Wang, 2008). The dilution hypothesis contends that $\mathrm{N}$ supply fails to keep up with the increased demand from stimulated biomass growth. Legumes, with their nitrogen-fixing symbionts, would be able to overcome such limitation because the additional carbohydrate acquired under $\mathrm{e}\left[\mathrm{CO}_{2}\right]$ could feed the $\mathrm{N}$-fixing symbiosis (Rogers et al., 2009). Indeed, field grown soybean did not show decreases in leaf $[\mathrm{N}]$ from about mid-season onwards, once the $\mathrm{N}$ fixing symbiosis had established (Rogers et al., 2006). Studies in chambers or high rainfall agro-ecosystems suggested that, in contrast to cereals, legume grains maintain protein concentrations under e $\left[\mathrm{CO}_{2}\right]$ (Jablonski et al., 2002; Taub et al., 2008). As N-fixation is more sensitive to water stress than biomass accumulation and leaf expansion (Serraj et al., 1998), in semi-arid environments N-fixation is likely interrupted by water stress and therefore biomass dilution of $[\mathrm{N}]$ might occur. Some recent reports have found small but significant decreases in grain protein in legumes which might be partially explained by water stress (Lam et al., 2012 in chickpea (Cicer arietinum); Bourgault et al., 2016 in field pea (Pisum sativum)).

It might be possible to take advantage of rising atmospheric $\left[\mathrm{CO}_{2}\right]$ by selecting for greater $\mathrm{CO}_{2}$ responsiveness in crop breeding programs either directly or by selecting traits that are associated with a greater response (Ainsworth et al., 2008; Tausz et al., 2013; Ziska et al., 2012). Intraspecific variability in the response to $\mathrm{e}\left[\mathrm{CO}_{2}\right]-$ a prerequisite for this approach - has been reported in soybean (Glycine max): Bishop et al. (2015) have found consistent differences in grain yield response to e $\left[\mathrm{CO}_{2}\right]$ among 18 cultivars grown under Free Air $\mathrm{CO}_{2}$ Enrichment (FACE) and suggested this is a heritable trait. They also suggested that high e $\left[\mathrm{CO}_{2}\right]$ response is related to a greater harvest index and a short stature. Similarly, Bunce (2008) investigated variability in the response to $\mathrm{e}\left[\mathrm{CO}_{2}\right]$ of 4 common bean (Phaseolus vulgaris) cultivars and suggested that greater grain yield response was associated with the ability to produce more pods under e $\left[\mathrm{CO}_{2}\right]$. Similarly, Ziska et al. (2001) showed that greater yield response in soybean was related to the ability of some cultivars to increase the seed production on auxiliary branches. In contrast, studies reporting a lack of response to e $\left[\mathrm{CO}_{2}\right]$ in one cultivar have often related this to limitations in the ability to use the additional carbohydrates. For example, Sicher et al. (2010) found that a dwarf cultivar of soybean did not show yield increases under e $\left[\mathrm{CO}_{2}\right]$. Grains of this cultivar were $75 \%$ smaller and had lower oil seed content than grains of normal cultivar. Taken together, these studies suggest that the response to $\mathrm{e}\left[\mathrm{CO}_{2}\right]$ might depend on both the capacity of the plant to utilise the additional carbohydrates produced under e $\left[\mathrm{CO}_{2}\right]$ and the effective translocation of resources to grains later in yield formation.

Lentil (Lens culinaris) is one of the oldest cultivated crops in the world and its production has more than quadrupled since the 1960s reaching a global production of over 5 million tonnes in 2013 (FAOSTAT, 2016). It is well-known as a nutritious grain and forms the basis of many traditional Asian and Middle Eastern recipes (Raghuvanshi and Singh, 2009). In Australia, it is grown as a winter crop under non-irrigated conditions, and therefore frequently subjected to terminal drought conditions. Further, the crop is often exposed to low temperatures during the vegetative stage and high temperature stress by pod filling (Materne and Siddique, 2009). Substantial efforts in breeding lentils in Australia are recent and expanding genetic variability is still seen as a major activity (Siddique et al., 2013). Intraspecific variability in many traits of interest is adequate and could be used in breeding programs (Erskine et al., 2009), although there is little published information on drought tolerance characteristics and no information on potential intraspecific variability in the response to e
$\left[\mathrm{CO}_{2}\right]$ in lentils.

In this study, we grew a range of lentil lines over three seasons in the Australian Grains FACE (AGFACE) facility. AGFACE is located in the south-eastern Australian grain cropping belt, with a typical semi-arid Mediterranean climate, making it a representative site for significant areas of global lentil production (Materne and Siddique, 2009). Therefore, this experimental set-up allowed us to address the following research questions:

- What are the effects of e[ $\left[\mathrm{CO}_{2}\right]$ on the growth and grain yield of lentil (Lens culinaris) grown under realistic drought conditions under Free Air $\mathrm{CO}_{2}$ Enrichment (FACE)?

- Does e $\left[\mathrm{CO}_{2}\right]$ decrease grain $[\mathrm{N}]$ in lentil?

- Is there genotypic variability in the response to $\mathrm{e}\left[\mathrm{CO}_{2}\right]$ in lentil cultivars?

\section{Materials and methods}

\subsection{Experimental site and growing conditions}

The Australian Grains Free Air $\mathrm{CO}_{2}$ Enrichment (AGFACE) facility is located near Horsham, Victoria ( $36^{\circ} 45^{\prime} 07^{\prime \prime S} 142^{\circ} 06^{\prime} 52^{\prime \prime} \mathrm{E}, 127 \mathrm{~m}$ above sea level). The site is cracking clay soil (Vertosol) with approximately $35 \%$ clay content at the surface increasing to $60 \%$ at $1.4 \mathrm{~m}$ depth. Long term average (based on 1981-2010 period) annual rainfall is $435 \mathrm{~mm}$, with approximately $320 \mathrm{~mm}$ falling during the winter growing season (from May to November inclusive). Average maximum and minimum temperatures are $17.6{ }^{\circ} \mathrm{C}$ and $5.3{ }^{\circ} \mathrm{C}$ respectively during the season, with July being the coldest month (Bureau of Meteorology, 2016). Maximum and minimum temperatures as well as rainfall data during the 2013-2015 growing seasons were recorded by an on-site weather station (MEA Premium Weather Station 103, Measurement Engineering Australia, Magill, SA, Australia; Fig. 1). Soil moisture was also monitored in 2014 and 2015, on a weekly basis in two cultivars to a depth of $1 \mathrm{~m}$ with a PR2 Profile Probe (Delta-T Devices, Cambridge, UK) (Fig. 2).

Elevated $\mathrm{CO}_{2}$ levels (target $550 \mu \mathrm{mol} \mathrm{mol}{ }^{-1}$ air) were maintained during daylight hours by injecting pure $\mathrm{CO}_{2}$ into the air on the upwind side from horizontal stainless-steel tubes so the gas would be carried across the ring. The tubes were positioned about $150 \mathrm{~mm}$ above the canopy and raised following the growth of the crop. Concentrations were maintained within $90 \%$ target $\left(495-605 \mu \mathrm{mol} \mathrm{mol}^{-1}\right.$ air) for $93-98 \%$ of the time. More details on the site and the $\mathrm{CO}_{2}$ exposure equipment are given in Mollah et al. (2009).

Plots were sown on 5 June 2013, 12 May 2014 and 26 May 2015. Plots were treated according to local practice with pre-emergence herbicides (simazine, dimethenamid-P, trifluralin, isoxaflutole, and/or glyphosate) prior to sowing and with haloxyfob approximately 4-8 weeks after emergence if required. In 2014, the insecticide dimetoate was also used to control aphids. Superphosphate was placed with the seed at sowing at $9 \mathrm{~kg} \mathrm{P} \mathrm{ha}^{-1}$ and $11 \mathrm{~kg} \mathrm{Sha}^{-1}$ each year. No nitrogen fertilizer was added, but seeds were inoculated with granular pea and lentil inoculant in 2013 and 2014 (Nodulator, BASF Corporation, Research Triangle Park, NC, USA), and peat-based inoculant in 2015 (NoduleN, New Edge Microbials Pty Ltd, Albury, NSW, Australia).

\subsection{Experimental design}

In each year (2013-2015), there were 4 ambient and 4 elevated $\mathrm{CO}_{2}$ octagonal main plots organised in bays each containing one ambient and one $\mathrm{e}\left[\mathrm{CO}_{2}\right]$ plot. The design within each plot differed from year to year. In 2013, plots were $8 \mathrm{~m}$ in diameter and split in half for a plus/ minus supplemental irrigation treatment. Six cultivars were organised in sub-plots of 2 rows $(0.55 \mathrm{~m})$ by $4 \mathrm{~m}$ in each half. However, because the supplemental irrigation treatment was omitted during this season 


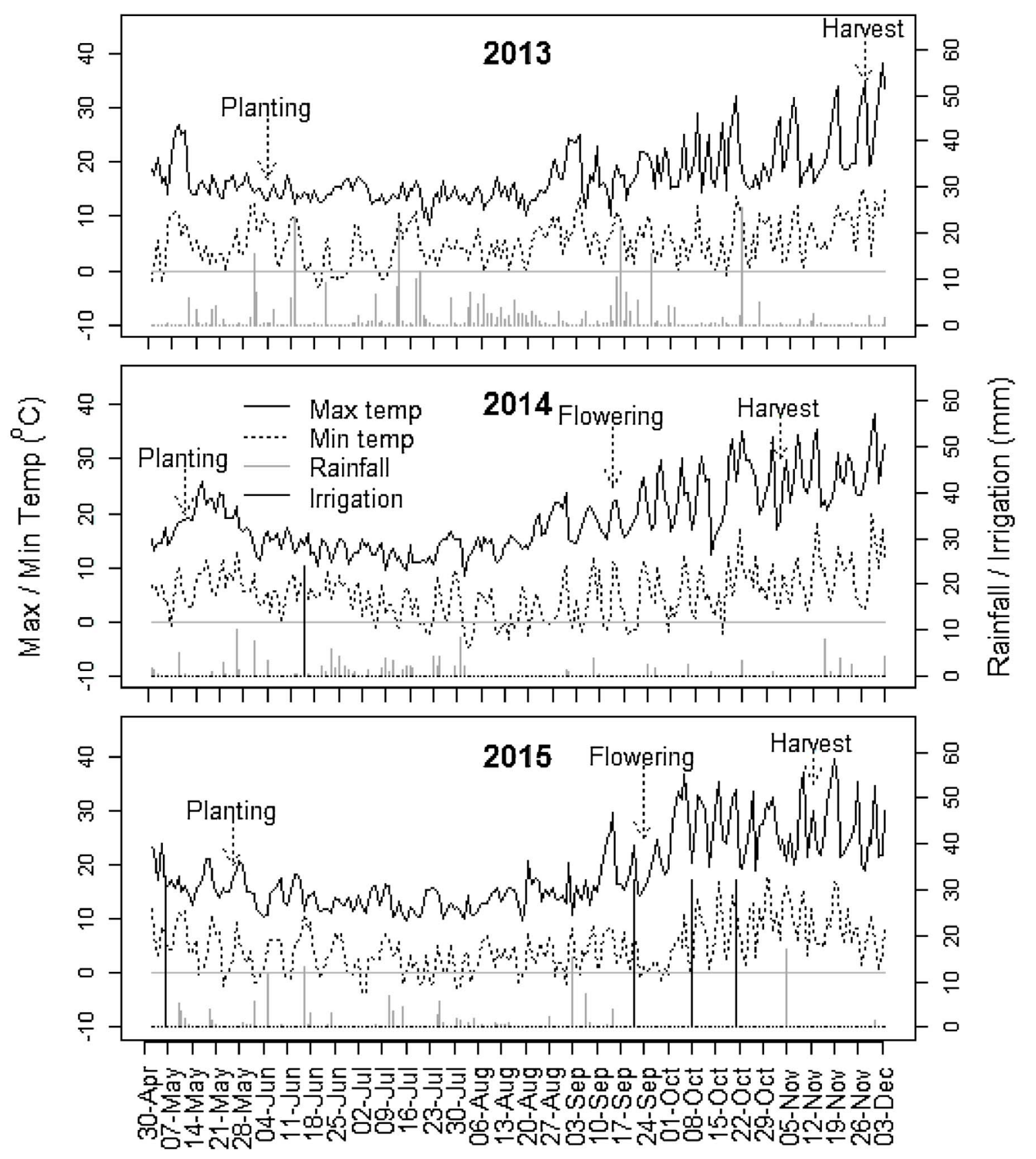

Fig. 1. Weather data recorded on-site in the 2013-2015 growing seasons in AGFACE (Horsham, Victoria, Australia) with arrows showing relevant events.

and emergence was uneven, the 'best' sub-plot (by emergence) per cultivar per ring was chosen for the harvest sampling. In 2014, plots were $4 \mathrm{~m}$ in diameter. The same six cultivars were organised in subplots of 4 rows $(0.976 \mathrm{~m})$ by $2 \mathrm{~m}$ length. In 2015, lentil sub-plots were included in predominantly wheat main plots, on adjacent edge subplots (6 rows or $1.5 \mathrm{~m}$ by $4 \mathrm{~m}$ length). Only PBA Ace and 05H010L07HS3010 were grown in 2015.

\subsection{Plant material}

Five lentil cultivars and one breeding line were selected to account for the genetic diversity present in the Australian collection. The cultivars Boomer and PBA Giant are large-seeded green lentil types, while PBA Ace, PBA Jumbo, Nipper and 05H010L-07HS3010 are red lentils. Nipper is a small-seeded lentil, PBA Ace and 05H010L07HS3010 are medium sized and PBA Jumbo is a large-seeded red lentil. The breeding line 05H010L-07HS3010 (abbreviated HS3010 in figures) also showed large biomass accumulation in favourable yield conditions, but with a smaller harvest index than commercial lines (M. Rodda, personal communication).

\subsection{Measurements}

Non-destructive measurements of canopy reflectance, from which Normalised Difference Vegetation Index (NDVI) was calculated, were taken with a CropCircle ACS-210 with GeoSCOUT GLS-400 data logger (Holland Scientific, Lincoln, NE, USA) as an indirect measurement of crop canopy development (Fitzgerald, 2010; Perry et al., 2012). These were taken approximately every week (2014) or fortnightly (2015) from the vegetative stage to the pod filling stage in 2014 and 2015.

Destructive samplings were conducted at flowering (2014 and 2015 only) and maturity stages. These correspond to the full bloom (R2) and full maturity (R8) stages (Erskine et al., 1990). At the flowering stage, aboveground biomass was harvested from a quadrat (central 2 rows by 

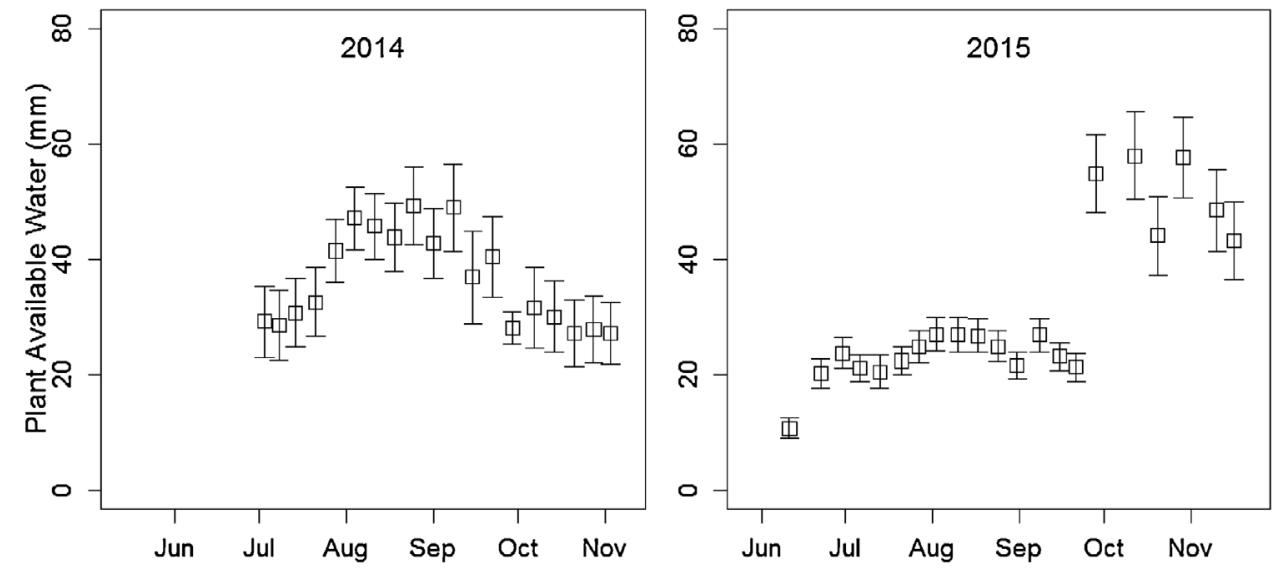

Fig. 2. Plant available water (mm) in lentil plots in the 2014 and 2015 growing seasons in AGFACE (Horsham, Victoria, Australia).

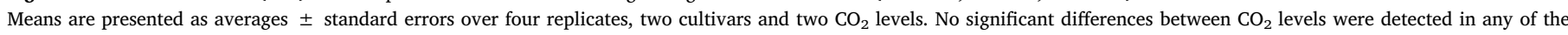
readings.

$0.25 \mathrm{~m}$ in 2014 or $0.12 \mathrm{~m}^{2}$; central 4 rows by $0.30 \mathrm{~m}$ in 2015 or $0.29 \mathrm{~m}^{2}$ ). A subsample was separated into leaves and stems. All samples were dried at $65-70{ }^{\circ} \mathrm{C}$ for at least $72 \mathrm{~h}$ and weighed for above-ground biomass determination. Leaf and stem samples were then ground and analysed for [N] by LECO Tru Mac Elemental Analyser (LECO Corporation, St. Joseph, MI, USA). At maturity in 2013, two $0.50 \mathrm{~m}$ rows were harvested (corresponding to $0.275 \mathrm{~m}^{2}$ ). In 2014, a quadrat of the central 2 rows by $0.20 \mathrm{~m}\left(0.10 \mathrm{~m}^{2}\right)$ was harvested and in 2015 , the quadrat was 4 rows by $0.30 \mathrm{~m}\left(0.29 \mathrm{~m}^{2}\right)$, also excluding the two outside rows. Samples were dried at $40{ }^{\circ} \mathrm{C}$ for $72 \mathrm{~h}$, then weighed for total above-ground biomass. Fully-formed pods (even if empty) were separated and counted, then threshed. Grains were weighed and seed count was also recorded. In 2013 and 2015, pods and seeds were determined on a sub-sample but in 2014 the samples were small enough that the pods and seeds were determined on the entire sample. Grain and straw were ground and analysed for $[\mathrm{N}]$ as described above. Post-flowering biomass accumulation, as a measure of an indeterminate growth habit, was calculated by subtracting the biomass accumulation at flowering from the total biomass accumulation at the maturity stage.

\subsection{Statistical analysis}

The experiment was designed as a complete block split-plot design. Years, $\left[\mathrm{CO}_{2}\right]$ treatments as the main plot (i.e 'rings'), and cultivars (the sub-plot) were considered fixed effects. Blocks and ring number (nested within blocks) were considered random effects. For yield and final biomass data, the variance was heterogeneous and correlated to means, so a log-transformation was performed before the statistical analysis.
Dependent variables were analysed using a mixed model analysis procedure using the AsREML algorithm (Butler et al., 2009; Gilmour et al., 1995 Gilmour et al., 1995; AsREML-R, VSN International, Hemel Hempstead, UK) as implemented in the R language (R Core Team, 2013). While the $\left[\mathrm{CO}_{2}\right]$ treatments are the same as rings within an individual year, having both a fixed term and a random term decouples the physical locations from the treatments across the three years, and ensures that the stratification of treatments is properly imposed in the analysis with AsREML as recommended by Butler et al. (2007); (Section 8.2). Wald tests were performed for the fixed effects. For repeated measures of NDVI during the course of the season, we performed a multivariate analysis with NDVI values for each date as dependent variables based on the same model as described above, but for each year separately, and with an antedependence variance-covariance structure to account for the correlation of residuals from measurements done on the same plots as suggested by Wolfinger (1996) and Smith et al. (2007).

\section{Results}

\subsection{Grain yield and yield components}

Grain yield increased in response to e $\left[\mathrm{CO}_{2}\right]$ and there was a wide range of relative responses between years $(32,138$, and $18 \%$ in 2013 , 2014 and 2015 respectively) (Fig. 3A). The absolute $\mathrm{CO}_{2}$ response in grain yield appeared to be constant at approximately $0.5 \mathrm{tha}^{-1}$ regardless of yield potential. This increase in yield was associated with an increase in total above-ground biomass measured at maturity (by
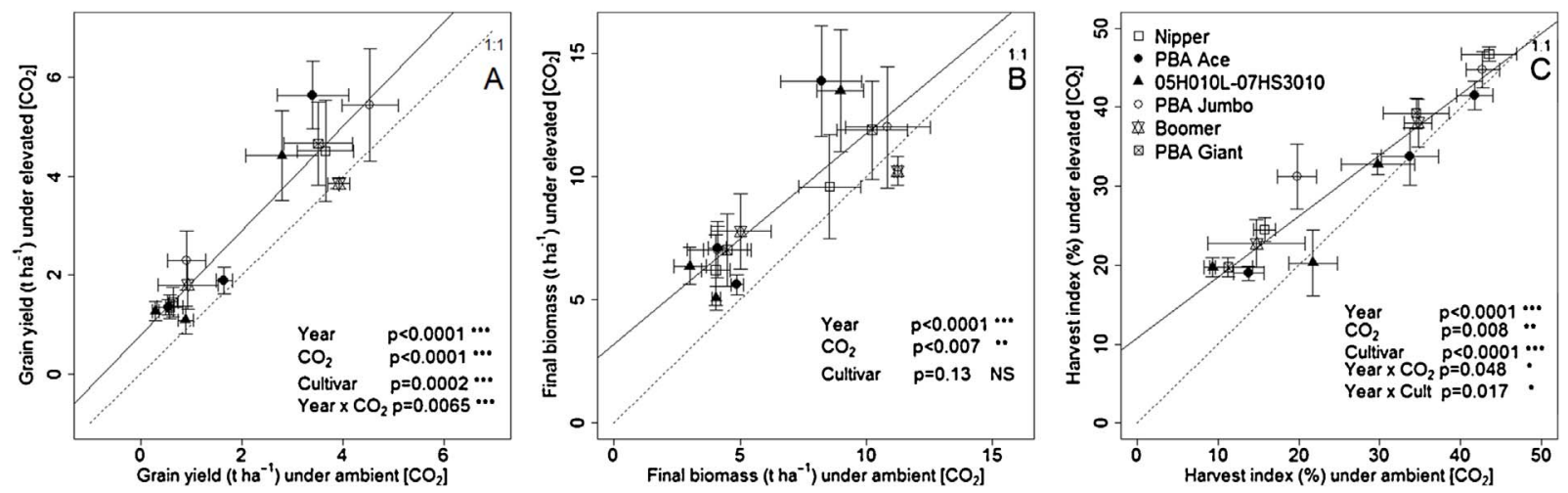

Fig. 3. Effects of elevated $\left[\mathrm{CO}_{2}\right]$ on grain yield (A), final above-ground biomass (B) and harvest index (C) for six lentil cultivars in AGFACE (2013-2015).

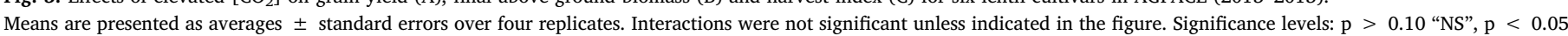
“*”, $\mathrm{p}<0.01$ “**”, $\mathrm{p}<0.001$ “***". 
Table 1

Effects of elevated $\left[\mathrm{CO}_{2}\right]$ on yield components for six lentil cultivars in AGFACE (2013-2015).

\begin{tabular}{|c|c|c|c|c|c|c|}
\hline & \multicolumn{2}{|l|}{2013} & \multicolumn{2}{|l|}{2014} & \multicolumn{2}{|l|}{2015} \\
\hline & Ambient $\left[\mathrm{CO}_{2}\right]$ & Elevated $\left[\mathrm{CO}_{2}\right]$ & Ambient $\left[\mathrm{CO}_{2}\right]$ & Elevated $\left[\mathrm{CO}_{2}\right]$ & Ambient $\left[\mathrm{CO}_{2}\right]$ & Elevated $\left[\mathrm{CO}_{2}\right]$ \\
\hline Cultivar & 100-seed weight $(\mathrm{g})$ & & & & & \\
\hline Nipper & 3.00 & 2.97 & 1.84 & 1.91 & & \\
\hline PBA Ace & 3.89 & 4.06 & 2.19 & 2.62 & 4.47 & 3.92 \\
\hline 05H010L-07HS3010 & 3.86 & 3.83 & 2.44 & 3.17 & 4.32 & 3.87 \\
\hline PBA Jumbo & 4.28 & 4.38 & 2.93 & 3.05 & & \\
\hline Boomer & 5.58 & 5.46 & 3.18 & 4.14 & & \\
\hline PBA Giant & 6.13 & 6.08 & 3.35 & 3.77 & & \\
\hline Cultivar means & 4.46 & 4.47 & 2.7 & 3.1 & 4.40 & 3.90 \\
\hline \multirow[t]{7}{*}{ Significance } & Year & **** & & & & \\
\hline & {$\left[\mathrm{CO}_{2}\right]$} & NS & & Ambient $\left[\mathrm{CO}_{2}\right]$ & 4.04 & \\
\hline & Cultivar & $* * * *$ & & Elevated $\left[\mathrm{CO}_{2}\right]$ & 3.98 & \\
\hline & Year $\times\left[\mathrm{CO}_{2}\right]$ & $* * * *$ & & & & \\
\hline & Year $\times$ Cultivar & $* * * *$ & & & & \\
\hline & Year $\times\left[\mathrm{CO}_{2}\right] \times$ Cultivar & NS & & & & \\
\hline & Pods $\left(\# \mathrm{~m}^{-2}\right)$ & & & & & \\
\hline Nipper & 8666 & 11462 & 3273 & 6075 & & \\
\hline PBA Ace & 6403 & 9150 & 1921 & 2976 & 4646 & 4357 \\
\hline 05H010L-07HS3010 & 6338 & 12108 & 978 & 3153 & 2929 & 3061 \\
\hline PBA Jumbo & 9036 & 10742 & 2682 & 6047 & & \\
\hline Boomer & 6172 & 9905 & 1647 & 2177 & & \\
\hline PBA Giant & 5029 & 6341 & 1627 & 3217 & & \\
\hline Cultivar means & 6941 & 9951 & 2021 & 3941 & 3788 & 3709 \\
\hline \multirow[t]{7}{*}{ Significance } & Year & $m * * *$ & & & & \\
\hline & {$\left[\mathrm{CO}_{2}\right]$} & *** & & Ambient $\left[\mathrm{CO}_{2}\right]$ & 4624 & \\
\hline & Cultivar & $* * * *$ & & Elevated $\left[\mathrm{CO}_{2}\right]$ & 6114 & \\
\hline & Year $\times\left[\mathrm{CO}_{2}\right]$ & NS & & & & \\
\hline & Year $\times$ Cultivar & NS & & & & \\
\hline & Year $\times\left[\mathrm{CO}_{2}\right] \times$ Cultivar & NS & & & & \\
\hline & Seed per pod (\#) & & & & & \\
\hline Nipper & 1.42 & 1.33 & 1.05 & 1.23 & & \\
\hline PBA Ace & 1.42 & 1.50 & 1.31 & 1.53 & 0.94 & 1.06 \\
\hline 05H010L-07HS3010 & 1.11 & 0.94 & 0.96 & 1.13 & 0.78 & 0.82 \\
\hline PBA Jumbo & 1.24 & 1.10 & 1.13 & 1.15 & & \\
\hline Boomer & 1.16 & 0.77 & 0.88 & 1.31 & & \\
\hline PBA Giant & 1.14 & 1.18 & 0.88 & 1.01 & & \\
\hline Cultivar means & 1.25 & 1.14 & 1.04 & 1.23 & 0.86 & 0.94 \\
\hline \multirow[t]{6}{*}{ Significance } & Year & 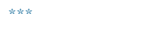 & & & & \\
\hline & {$\left[\mathrm{CO}_{2}\right]$} & NS & & Ambient $\left[\mathrm{CO}_{2}\right]$ & 1.03 & \\
\hline & Cultivar & $* * *$ & & Elevated $\left[\mathrm{CO}_{2}\right]$ & 1.04 & \\
\hline & Year $\times\left[\mathrm{CO}_{2}\right]$ & $* * * *$ & & & & \\
\hline & Year $\times$ Cultivar & $* *$ & & & & \\
\hline & Year $\times\left[\mathrm{CO}_{2}\right] \times$ Cultivar & " & & & & \\
\hline
\end{tabular}

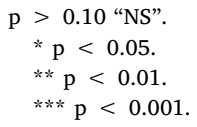

32\%; Fig. 3B), harvest index (by 16\%; Fig. 3C) and in the number of pods per $\mathrm{m}^{2}$ (by $55 \%$; Table 1 ). Harvest index increased relatively more under e $\left[\mathrm{CO}_{2}\right]$ with low values under ambient conditions (Fig. 3C): in 2014, HI increased by 60\% compared to 7 and $-3 \%$ in 2013 and 2015 respectively, and this is confirmed by a significant year by $\left[\mathrm{CO}_{2}\right]$ interaction.

There were large differences in grain yield and yield components between years (Table 1), reflecting the variable climate typical of the region. Elevated $\left[\mathrm{CO}_{2}\right]$ consistently increased the number of pods per $\mathrm{m}^{2}$, but the effect on seed weight and on the number of seeds per pod was dependent on the year. In 2013 and 2015, when the seed weight was relatively high under ambient $\left[\mathrm{CO}_{2}\right]\left(\mathrm{a}\left[\mathrm{CO}_{2}\right]\right)$, e $\left[\mathrm{CO}_{2}\right]$ had no effect, but it increased seed weight in 2014 under terminal drought conditions (Table 1). Similarly, the number of seeds per pod, on average, were increased by $\mathrm{e}\left[\mathrm{CO}_{2}\right]$ in 2014 and 2015, but not in 2013, although the cultivars PBA Ace and PBA Giant showed a positive response to $\left[\mathrm{CO}_{2}\right]$ in all three years (Table 1 ).

Cultivar differences were also significant for most of these parameters, except for biomass accumulation which was similar for all cultivars. Expression of cultivar differences was consistent with cultivar characterisations. For example, 05H010L-07HS3010 showed lower grain yield and a low harvest index (Fig. 3A,C), while the cultivar Nipper showed small grain size (Table 1 ). No cultivar by $\left[\mathrm{CO}_{2}\right]$ interactions were detected for these parameters, which suggests all cultivars responded similarly to $\mathrm{e}\left[\mathrm{CO}_{2}\right]$.

\subsection{Growth}

Above-ground biomass at flowering was increased by e $\left[\mathrm{CO}_{2}\right]$ by $18 \%$ (Fig. 4). The green lentil cultivar PBA Giant showed the highest biomass accumulation at this growth stage with 05H010L-07HS3010 the smallest. Biomass accumulation from flowering to maturity was increased substantially under e $\left[\mathrm{CO}_{2}\right]$ (a $50 \%$ increase, Fig. 4). However, year main effects were not significant for these parameters, despite contrasting water availability in 2014 and 2015.

The Normalised Difference Vegetation Index (NDVI) as an indirect measure of crop canopy development showed significant $\left[\mathrm{CO}_{2}\right]$ effects with the NDVI values being greater under $\mathrm{e}\left[\mathrm{CO}_{2}\right]$ at every time point 


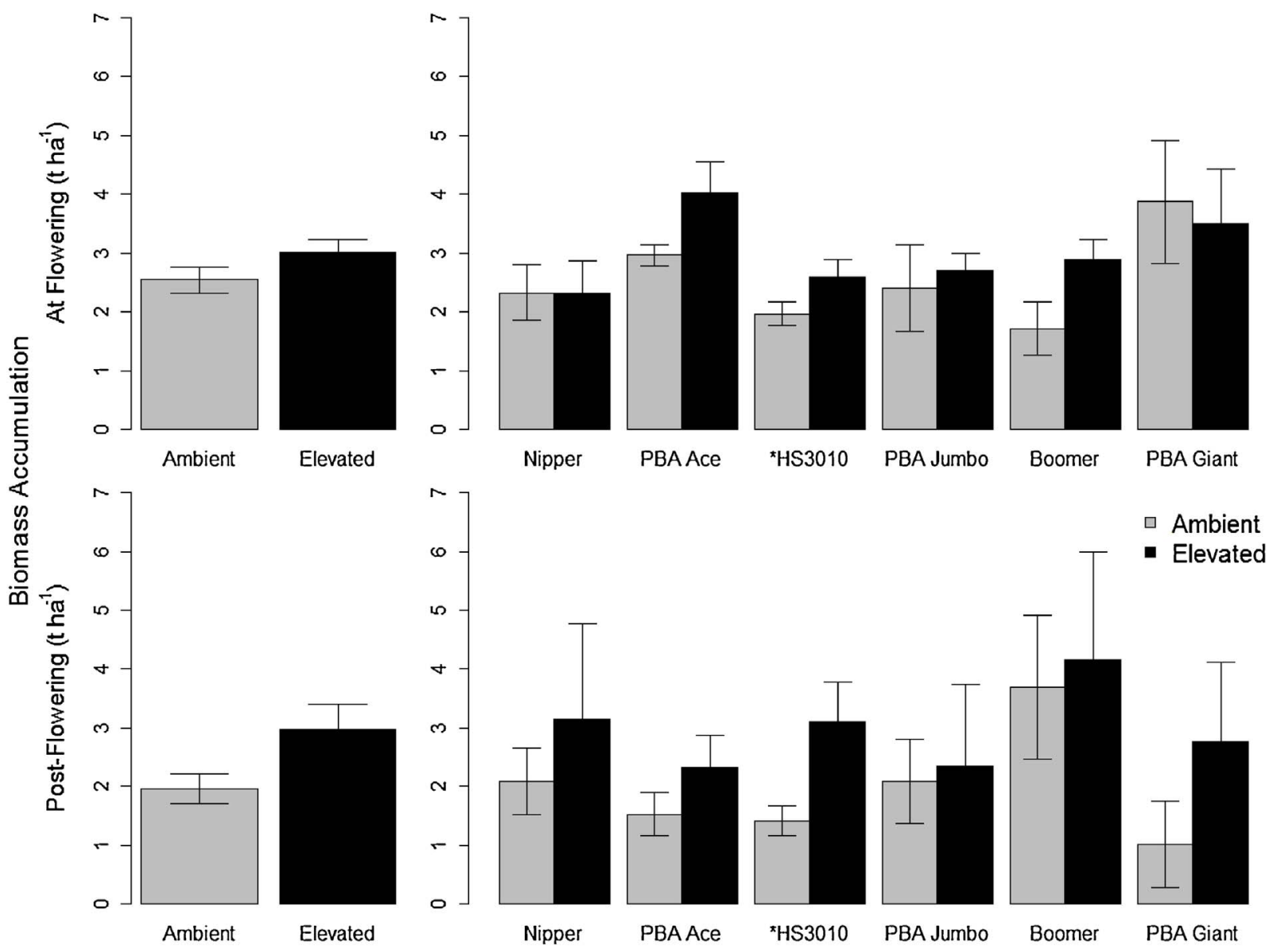

Fig. 4. Biomass accumulation at flowering and from flowering to maturity in six lentil cultivars in AGFACE (2014-2015).

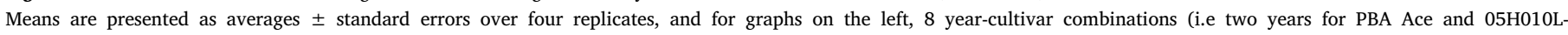

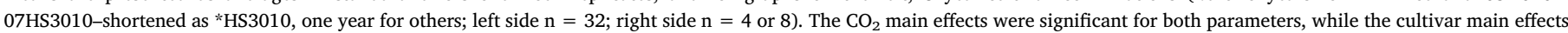

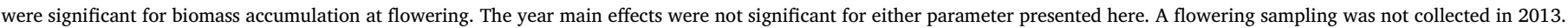

(Fig. 5). Time by cultivar interactions were also detected in both years (not shown). In 2014 there were large differences between cultivars at the beginning of measurements, with PBA Ace showing the highest crop canopy cover, and 05H010L-07HS3010 showing the lowest but catching up later in the season. In 2015, these same cultivars started off at the same point, but PBA Ace stabilised at higher NDVI values than 05H010L-07HS3010. There was also a significant $\left[\mathrm{CO}_{2}\right]$ by cultivar interaction in 2014 where 05H010L-07HS3010 showed lower NDVI values under ambient conditions compared to other cultivars while it reached similar levels under e[ $\left[\mathrm{CO}_{2}\right]$ (not shown). However, emergence was lower in 2014 than in 2015 which might explain part of the crop canopy cover differences.

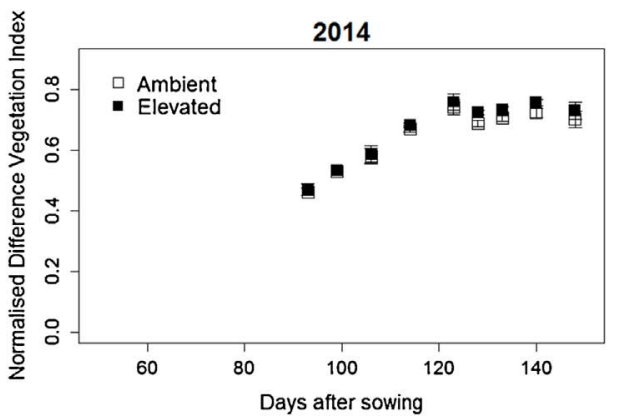

\subsection{Above-ground nitrogen concentration and content at flowering}

Above-ground nitrogen concentration $([\mathrm{N}])$ at flowering decreased by $4 \%$ under e[ $\left[\mathrm{CO}_{2}\right]$ (Fig. 6). This was due to a decrease in leaf $[\mathrm{N}]$ as stem $[\mathrm{N}]$ was unaffected by the $\left[\mathrm{CO}_{2}\right]$ treatment. There were also cultivar differences with PBA Jumbo showing the highest [N] concentration in both leaves and stems while PBA Giant showed the lowest concentration (Fig. 6). Total $\mathrm{N}$ content in the above-ground biomass at the flowering stage increased under $\mathrm{e}\left[\mathrm{CO}_{2}\right]$ (not shown) because of greater biomass under e $\left[\mathrm{CO}_{2}\right]$, but cultivar differences were marginally significant (with 05H010L-07HS3010 showing the smallest $\mathrm{N}$ accumulation). Again, no $\left[\mathrm{CO}_{2}\right]$ by cultivar interactions were found for these parameters.

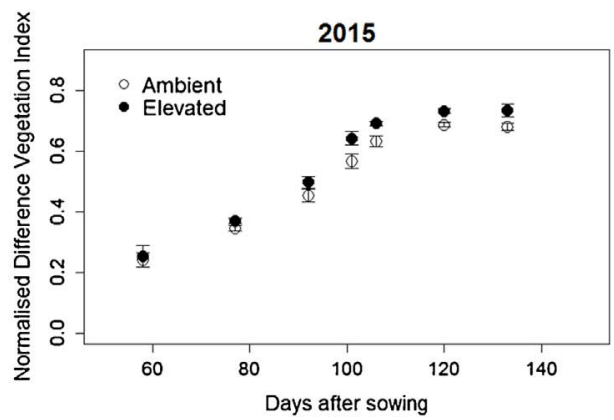

Fig. 5. Time course of the Normalized Difference Vegetation Index (NDVI) values in six lentil cultivars in AGFACE (2014-2015).

Each point is presented \pm its standard error and represents the average over four replicates $(\mathrm{n}=4)$. The $\left[\mathrm{CO}_{2}\right]$ main effect was significant in both years. 

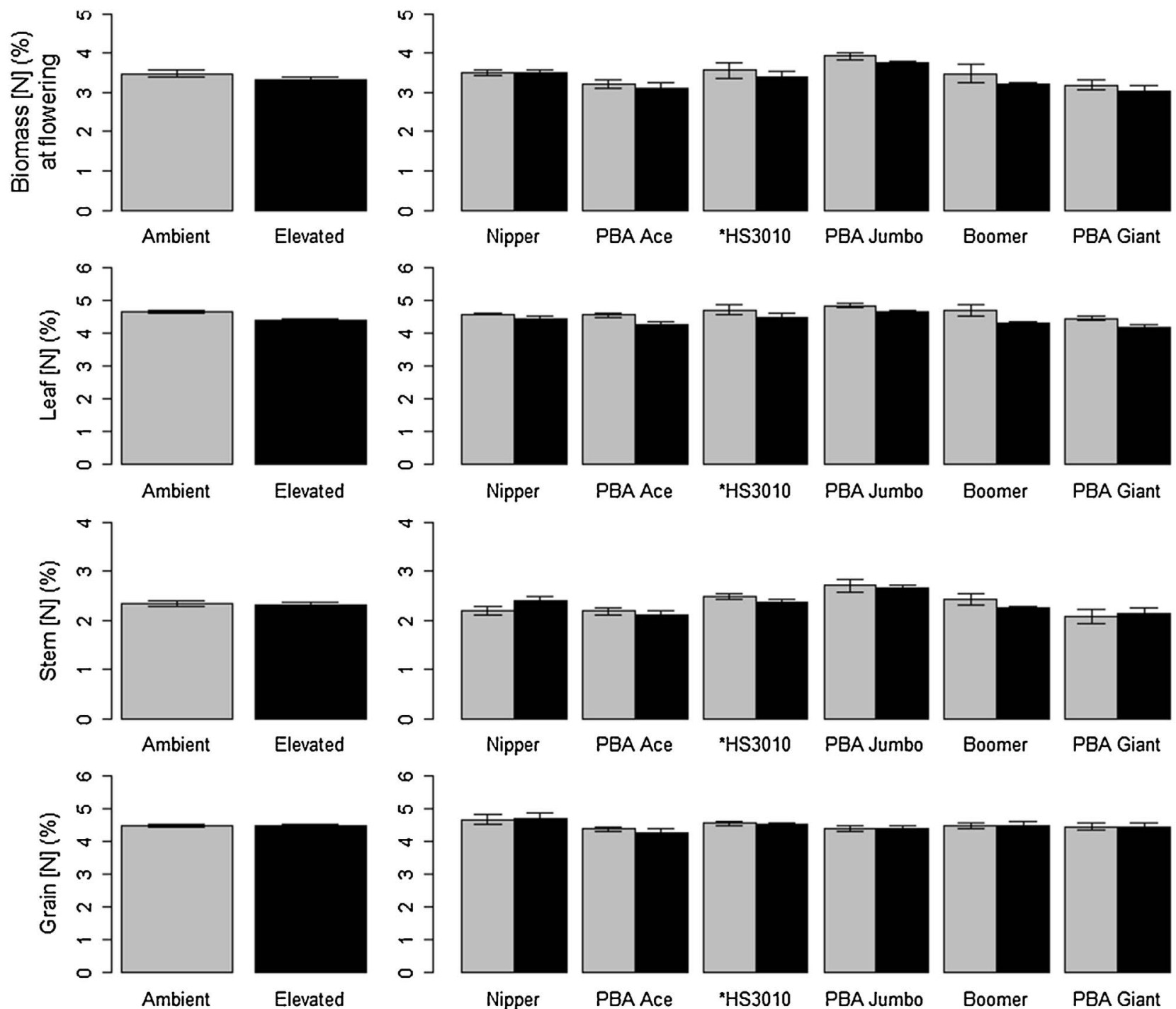

PBA Ace

*HS3010

PBA Jumbo

Boomer

PBA Giant

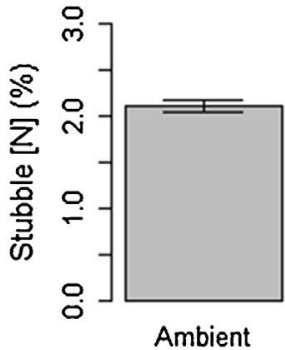

Elevated
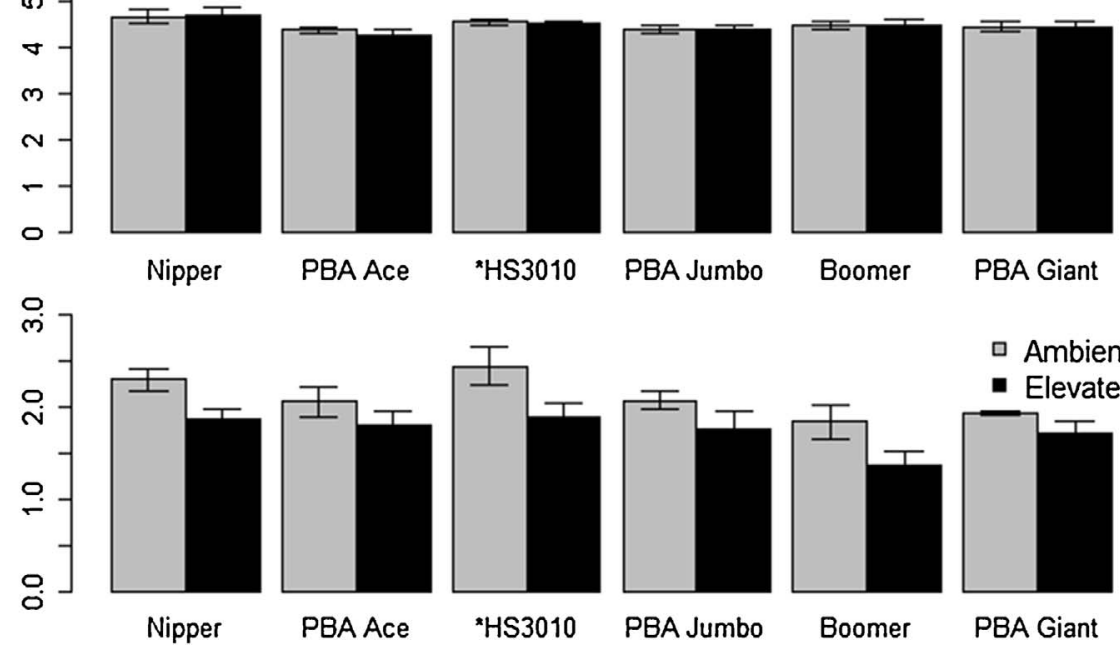

PBA Giant
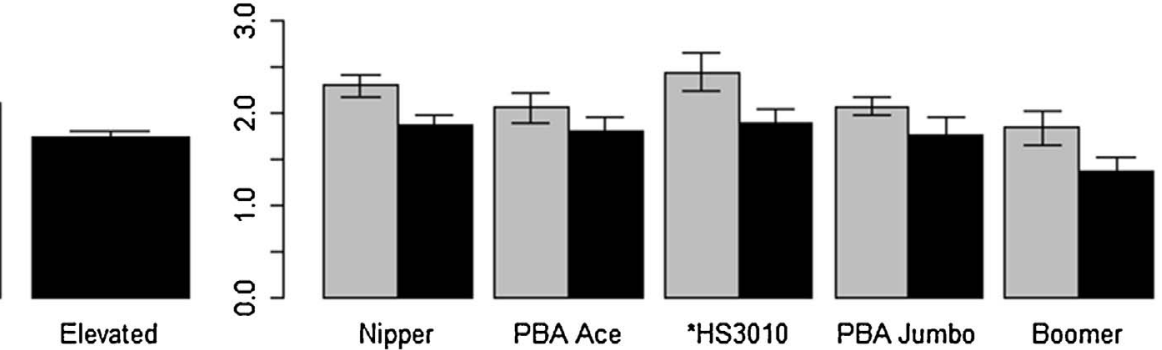

․ Ambient

- Elevated

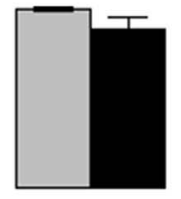

PBA Giant

Fig. 6. Nitrogen concentration at flowering and maturity in six lentil cultivars in AGFACE (2013-2015).

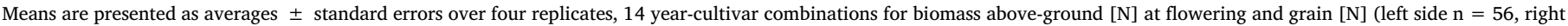

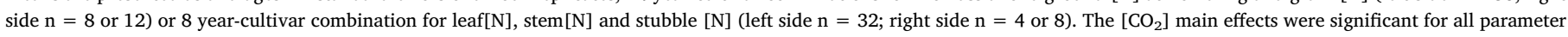

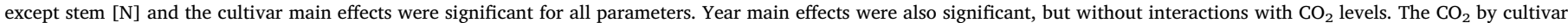
interaction was not significant for any of the parameters presented here.

\subsection{Nitrogen concentration and content in grains and stubble}

Grain $[\mathrm{N}]$ was slightly but significantly decreased by $2 \%$ with e $\left[\mathrm{CO}_{2}\right]$ and this was consistent between cultivars (Fig. 6). The smallseeded red lentil cultivar Nipper had the highest grain [N], while the large red lentil PBA Jumbo had the lowest. Stubble [N] was lower by $22 \%$ under e $\left[\mathrm{CO}_{2}\right]$ (Fig. 6), but there was a trend for total $\mathrm{N}$ in the stubble to be higher under $\mathrm{e}\left[\mathrm{CO}_{2}\right](\mathrm{p}=0.09)$ because of higher stubble biomass (64.5 compared to $81.4 \mathrm{~kg} \mathrm{ha}^{-1}$ under e $\left[\mathrm{CO}_{2}\right]$ ). There were significant differences between cultivars in the stubble $[\mathrm{N}]$ with green lentils exhibiting lower $[\mathrm{N}]$ in the stubble than red lentils, but no differences in the response to $\mathrm{e}\left[\mathrm{CO}_{2}\right]$ between cultivars were found (Fig. 6). The nitrogen harvest index (nitrogen content in grains divided by the amount of nitrogen in above-ground biomass) was increased under $\mathrm{e}\left[\mathrm{CO}_{2}\right]$, but only at lower levels with a similar pattern to the grain harvest index (Fig. 3C).

\section{Discussion}

Grain yield increases (18, 32 and 138\%) reported here with e[ $\left[\mathrm{CO}_{2}\right]$ are relatively large compared to previous FACE studies in two years out of three. Other FACE studies with legumes include the SoyFACE 
experiment (Illinois, USA), where soybean yields increased on average by $15 \%$ (Morgan et al., 2005) and from 0 to $22 \%$ depending on the cultivar in a different experiment (Bishop et al., 2015). The mini-FACE array at the Chinese Academy of Agricultural Sciences (Changping, China) also investigated soybean and showed that one cultivar did not respond while the other showed a $26 \%$ increase in yield with $\mathrm{e}\left[\mathrm{CO}_{2}\right]$ (Hao et al., 2012). Mungbean (Vigna radiata) was also grown at the Chinese mini-FACE and showed yield increases of 14\% (Gao et al., 2015). Finally, the Australian Grains Free Air $\mathrm{CO}_{2}$ Enrichment (AGFACE) site (Horsham, Australia) investigated field peas from 2010 to 2012, producing average grain yield responses of $26 \%$ (Bourgault et al., 2016).

The relative increase in yields under e[ $\left[\mathrm{CO}_{2}\right]$ may be greater with decreasing water availability (Gifford, 1979), as e $\left[\mathrm{CO}_{2}\right]$ improves plant water use efficiency (Leakey et al., 2009). Comparisons between FACE experiments for the response to e $\left[\mathrm{CO}_{2}\right]$ are difficult because, apart from climatic differences, many additional factors potentially contribute to differences in response - species, soils, genotypes, nutritional levels, etc. However, in this present study, we had three very contrasting years. In 2013, there were frequent rainfall events during the entire season. In 2014, the season started relatively wet, but the crop experienced a terminal drought, while in 2015 , drought was relieved after flowering with several irrigation events. The relative response for these years was $32 \%, 138 \%$ and $18 \%$ respectively and the absolute response in grain yield appeared to be more or less constant at approximately $0.5 \mathrm{t} \mathrm{ha}^{-1}$ regardless of yield potential. As demonstrated by Gifford (1979) in a controlled environment study, it is possible that a crop failure under a $\left[\mathrm{CO}_{2}\right]$ might result in some small yield under $\mathrm{e}\left[\mathrm{CO}_{2}\right]$. In this case, the relative response to $\mathrm{e}\left[\mathrm{CO}_{2}\right]$ becomes infinite, although the absolute response might be small. Are relative responses then appropriate to evaluate grain yield response to e $\left[\mathrm{CO}_{2}\right]$ when yields under a $\left[\mathrm{CO}_{2}\right]$ are close to a crop failure? Regardless, we also observed a greater response in 2013, a wet year, compared to 2015, so the existence of water stress might not be enough to promote a greater response to $\mathrm{e}\left[\mathrm{CO}_{2}\right]$. A greater response to e $\left[\mathrm{CO}_{2}\right]$ might only be expected under conditions of terminal drought, when water saved from growth under $\mathrm{e}\left[\mathrm{CO}_{2}\right]$ is then available during pod filling. Further investigations are warranted to confirm this as we could not detect differences in soil moisture data between $\mathrm{a}\left[\mathrm{CO}_{2}\right]$ and $\mathrm{e}\left[\mathrm{CO}_{2}\right]$ to support this hypothesis. However, Manschadi et al. (2006) suggested that water savings below detection thresholds could have substantial effects on grain yield.

Biomass accumulation between flowering and maturity was substantially increased by e $\left[\mathrm{CO}_{2}\right](50 \%)$ and substantially more stimulated than biomass accumulation from planting to flowering (18\%). Lentil is an indeterminate crop that can continue to produce biomass including vegetative structures past flowering. The relatively larger increase in biomass post flowering suggests that the indeterminate growth habit provides vegetative sinks in addition to reproductive sinks. There were similar increases in biomass gain after flowering in both 2014 and 2015, despite large differences in soil water availability at this stage of the crop development (Fig. 2). However, there were large differences in harvest index (7, 60 and $-3 \%$ for 2013, 2014 and 2015 respectively), translating to differences in grain yield. To our knowledge, there is only one other report of e $\left[\mathrm{CO}_{2}\right]$ increasing harvest index in crops: Fitzgerald et al. (2016) reported a significant increase in wheat harvest index, but only for one year and one site (Walpeup in Victoria, Australia, but not AGFACE at Horsham). Field studies that reported data on the harvest index of legumes include Bishop et al. (2015) who showed an average reduction of 5\% in harvest index in soybean and Bourgault et al. (2016) who showed no change from $\mathrm{e}\left[\mathrm{CO}_{2}\right]$ in field peas. Other AGFACE studies with w5 heat performed on the same site also showed no change in harvest index (Tausz-Posch et al., 2012; Tausz-Posch et al. 2015). Manderschied and Weigel (1997), who investigated historical cultivars that differed in harvest index, also showed that there was no change in $\mathrm{HI}$ with $\mathrm{e}\left[\mathrm{CO}_{2}\right]$ for any of the cultivars tested. Improvements in water use efficiency, especially if this leads to increased water availability at the pod filling stage, could explain the increase in harvest index observed in lentil, but again, we could not detect these differences in soil moisture data.

The decrease in leaf and grain $[\mathrm{N}]$ in lentils in this study appears contrary to what is commonly reported in the literature (Jablonski et al., 2002; Myers et al., 2014; Rogers et al., 2006), although the decrease in grain $[\mathrm{N}]$, though significant, was relatively small. In nitrogen fixing legumes, the additional assimilates could help feed the $\mathrm{N}$-fixing symbiosis and thereby avoid decreases in leaf and grain [N] (Rogers et al., 2009). In SoyFACE, field grown soybean did not show decreases in leaf $[\mathrm{N}]$ under $\mathrm{e}\left[\mathrm{CO}_{2}\right]$ from about mid-season onwards, once the N-fixing symbiosis had established (Roger et al., 2006). In this present study, we observed poor nodulation in 2014 which could explain decreases in tissue [N] as the lentils may have depended on soil nitrogen, but nodulation was adequate in 2015 . Yet, both leaf and grain [N] were depressed regardless of nodulation levels. This decrease in tissue [N] could potentially be explained by a number of hypotheses (reviewed by Taub and Wang, 2008), including the natural dilution of [N] with growth (Coleman et al., 1993) or higher photosynthetic efficiency leading to reduced nitrogen allocations to leaves (Moore et al., 1999). This is difficult to ascertain in this study because of the limited number of destructive samplings. Other hypotheses include decreased transpiration flow (McGrath and Lobell, 2013), or inhibition of nitrate assimilation (Bloom et al., 2014), although in the context of this study, the latter is not immediately apparent, as both poor and well nodulated crops showed the same decrease in tissue $[\mathrm{N}]$.

The identification of consistent genotypic variability in the response to $\left[\mathrm{CO}_{2}\right]$ is a prerequisite to use this information in breeding programs. Unlike the studies by Bishop et al. (2015) in soybean and Bunce (2008) in common bean, we could not detect differences between the cultivars tested in their response to $\left[\mathrm{CO}_{2}\right]$ for grain yield or other parameters observed. Traits related to source-sink relationships are candidate traits that might impact the response to $\mathrm{e}\left[\mathrm{CO}_{2}\right]$ (Tausz et al., 2013). Traits such as a determinate growth habit (Ainsworth et al., 2004), small seeds (Sicher et al., 2010) and low harvest index (Bishop et al., 2015) could limit the capacity of plants to utilise the additional assimilates provided by $\mathrm{e}\left[\mathrm{CO}_{2}\right]$. In this study, we used genotypic variability in some of these traits: 1) the cultivar Nipper had the expected small seeds with a grain size of $2.8 \mathrm{~g}$ per 100 seeds, while the breeding line PBA Giant had a grain size of $5.1 \mathrm{~g}$ per 100 seeds (Table 1); 2) the breeding line 05H0101L-07HS3010 had the lowest harvest index compared to PBA whereas Jumbo which had the highest (Fig. 3C), and 3) the cultivar PBA Giant tended to have the lowest biomass accumulation post-flowering, while the Boomer had the highest (Fig. 4). Yet, all of these cultivars showed similar benefits from $\mathrm{e}\left[\mathrm{CO}_{2}\right]$ for grain yield. While these traits might be related to sink limitation, they might not be sufficient to cause sink limitation and lower the response to e $\left[\mathrm{CO}_{2}\right]$. We therefore suggest the lentil cultivars selected were not sink-limited under e $\left[\mathrm{CO}_{2}\right]$. Whitehead et al. (2014) have found that seed yield improvement in lentils has been associated with higher biomass and occurred independently of improvements in harvest index. It is possible that grain yield in lentil is source-limited, in which case, it might be worth looking for genotypic variability in photosynthetic assimilation rates.

\section{Conclusion}

In this study, $\mathrm{e}\left[\mathrm{CO}_{2}\right]$ increased yields by approximately $0.5 \mathrm{tha}^{-1}$ (relative increase ranging from 18 to $138 \%$ ) by increasing both biomass accumulation (by 32\%) and the harvest index (by up to 60\%). The response of grain yield and harvest index varied with season, with the greatest response in both parameters observed during a terminal drought. Biomass accumulation post-flowering was increased considerably by $\mathrm{e}\left[\mathrm{CO}_{2}\right]$ (a $50 \%$ increase), suggesting that the indeterminate growth habit of lentil provides vegetative sinks in addition to reproductive sinks. Grain yield in lentil appears to be source limited, and 
traits associated with carbon assimilation might be better candidates to improve response to $\left[\mathrm{CO}_{2}\right]$ as we were not able to detect differences in the response to elevated $\left[\mathrm{CO}_{2}\right]$ for grain yield in cultivars that differed in biomass accumulation, seed size or harvest index. Further research is warranted to explain decreases in tissue [N] in well nodulated lentil crops grown under e[ $\left[\mathrm{CO}_{2}\right]$ and to explain why lentil appears to be the only crop to increase harvest index under $\mathrm{e}\left[\mathrm{CO}_{2}\right]$.

\section{Acknowledgements}

Research at the Australian Grains Free Air Carbon dioxide Enrichment (AGFACE) facility is jointly run by the Victorian Government and the University of Melbourne and receives substantial additional funding from the Australian Commonwealth Department of Agriculture and Water Resources (DAFWR) and the Grains Research and Development Corporation (GRDC). We wish to acknowledge the crucial contributions of Mahabubur Mollah (AGFACE research engineer) and Russel Argall (senior technical officer) and their team in running and maintaining the AGFACE facility, as well as Samuel Henty, Shahnaj Parvin and other team members from the University of Melbourne for technical help.

\section{References}

Ainsworth, E.A., Long, S.P., 2005. What have we learned from 15 years of free-air $\mathrm{CO}_{2}$ enrichment (FACE)? A meta-analytic review of the responses of photosynthesis, canopy properties and plant production to rising $\mathrm{CO}_{2}$. New Phytol. 165, 351-372.

Ainsworth, E.A., Rogers, A., Nelson, R., Long, S.P., 2004. Testing the source-sink hypothesis of down-regulation $\mathrm{f}$ photosynthesis in elevated $\left[\mathrm{CO}_{2}\right]$ in the field with single gene substitutions in Glycine max. Agric. Forest Meteorol. 122, 85-94.

Ainsworth, E., Beier, C., Calfapietra, C., Ceulemans, R., Durand-Tardif, M., Farquhar, G.D., Godbold, D.L., Hendry, G.R., Hickler, T., Kaduk, J., Karnosky, D.F., Kimball, B., Körner, C., Koornneef, M., Lafarge, T., Leakey, A.D., Lewin, K.F., Long, S.P., Manderscheid, R., McNeil, D.L., Mies, T.A., Miglieta, F., Morgan, J.A., Nagy, J., Norby, R.J., Norton, R.M., Percy, K.E., Rogers, A., Soussana, J.-F., Stitt, M., Weigel, H.-J., White, J.W., 2008. Next generation of elevated $\left[\mathrm{CO}_{2}\right]$ experiments with crops: a critical investment for feeding the future world. Plant. Cell Environ. 31, 1317-1324.

Bishop, K.R., Betzelberger, A.M., Long, S.P., Ainsworth, E.A., 2015. Is there potential to adapt soybean (Glycine max Merr.) to future $\left[\mathrm{CO}_{2}\right]$ ? An analysis of the yield response of 18 genotypes in free- air $\mathrm{CO}_{2}$ enrichment. Plant. Cell Environ. 38, 1765-1774.

Bloom, A.J., Burger, M., Kimball, B., Ointer Jr., P.J., 2014. Nitrate assimilation is inhibited by elevated $\mathrm{CO}_{2}$ in field-grown wheat. Nat. Clim. Change 4, 477-480.

Bourgault, M., Brand, J., Tausz, M., Fitzgerald, G.J., 2016. Yield: growth and grain nitrogen response to elevated $\mathrm{CO}_{2}$ of five field pea (Pisum sativum L.) cultivars in a low rainfall environment. Field Crop Res.h 196, 1-9.

Bunce, J.A., 2008. Contrasting responses of seed yield to elevated carbon dioxide under field conditions within Phaseolus vulgaris. Agric. Ecosyst. Environ. 128, 219-224.

Bureau of Meteorology, 2016. Climate Data Online Database (Horsham Polkemmet Rd VIC). Australian Government. http://www.bom.gov.au/climate/data/. (Accessed 18 January 2016).

Butler, D.G., Cullis, B.R., Gilmour, A.R., Gogel, B.J., 2007. ASReml-R reference manual Queensland Department Primary Industries and Fisheries. Toowoomba, QLD, Australia $148 \mathrm{pp}$.

Coleman, J.S., McConnaughay, K.D.M., Bazzaz, F.A., 1993. Elevated $\mathrm{CO}_{2}$ and plant nitrogen-use: is reduced tissue nitrogen concentration size dependent? Oecologia 93, $195-200$.

Deryng, D., Elliott, J., Folberth, C., Müller, C., Pugh, T.A.M., Boote, K.J., Conway, D., Ruane, A.C., Gerten, D., Jones, J.W., Khabarov, N., Olin, S., Schaphoff, S., Schmid, E., Yang, H., Rosenzweig, C., 2016. Regional disparities in the beneficial effects of rising CO2 concentrations on crop water productivity. Nat. Clim. Change 6 (8), 786-790. http://dx. doi.org/10.1038/nclimate2995.

Erskine, W., Muehlbauer, F.J., Sarker, A., Shama, A., 2009. Chapter 1: introduction. In: Erskine, W., Muehlbauer, F.J., Sarker, A., Shama, A. (Eds.), The Lentil: Botany, Production and Uses. CAB International Cambridge, MA, USA, pp. 1-3.

FAOSTAT, 2016. Food and Agriculture Organisation of the United Nations Statistics Division. http://faostat3.fao.org/home/E. (Accessed 5 February 2016).

Fitzgerald, G.J., Tausz, M., O'Leary, G., Mollah, M.R., Tausz-Posch, S., Seneweera, S., Mock, I., Löw, M., Partington, D.L., McNeil, D., Norton, R.M., 2016. Elevated atmospheric $\left[\mathrm{CO}_{2}\right]$ can dramatically increase wheat yields in semi-arid environments and buffer against heat waves. Global Change Biol. 22 (6), 2269-2284.

Fitzgerald, G.J., 2010. Characterizing vegetation indices derived from active and passive sensors. Int. J. Remote Sens. 31 (16), 4335-4348.

Gao, J., Seneweera, S., Li, P., Zong, Y.-Z., Dong, Q., Lin, E., Hao, X., 2015. Leaf photosynthesis and yield components of mung bean under fully open-air elevated $\left[\mathrm{CO}_{2}\right]$. J. Integr. Agric. 14 (5), 977-983.

Gifford, R.M., 1979. Growth and yield of $\mathrm{CO}_{2}$-enriched wheat under water-limited conditions. Aus. J. Plant Physiol. 6, 367-378.

Gilmour, A.R., Thompson, R., Cullis, B.R., 1995. Average information REML: An efficient algorithm for variance component estimation in linear mixed models. Biometrics 51, $1440-1450$.

Hao, X.Y., Han, X., Lam, S.K., Wheeler, T., Ju, H., Wang, H.R., Li, Y.C., Lin, E.D., 2012.
Effects of fully open-air $\left[\mathrm{CO}_{2}\right]$ elevation on leaf ultrastructure, photosynthesis, and yield of two soybean cultivars. Photosynthetica 50, 362-370.

Intergovernmental Panel on Climate Change (IPCC), 2014. Climate Change 2014: Synthesis Report. Contribution of Working Groups I, II and III to the Fifth Assessment Report of the Intergovernmental Panel on Climate Change. In: Pachauri, R.K., Meyer, L.A. (Eds.), IPCC, Geneva Switzerland (151 pp).

Jablonski, L.M., Wang, X., Curtis, P., 2002. Plant reproduction under elevated $\mathrm{CO}_{2}$ conditions: a meta-analysis of reports on 79 crops and wild species. New Phytol. 156, 9-26.

Lam, S.K., Chen, D., Norton, R., Armstrong, R., 2012. Does phosphorus stimulate that effect of elevated $\left[\mathrm{CO}_{2}\right]$ on growth and symbiotic nitrogen fixation of grain and pasture legumes? Crop Pasture Sci. 63, 53-62.

Leakey, A.D.B., Ainsworth, E.A., Bernacchi, C.J., Rogers, A., Long, S.P., Ort, D.R., 2009 Elevated $\mathrm{CO}_{2}$ effects on plant carbon, nitrogen, and water relations: six important lessons from FACE. J. Exp. Bot. 60 (10), 2859-2876.

Manderschied, R., Weigel, H.J., 1997. Photosynthetic and growth responses of old and modern spring wheat cultivars to atmospheric $\mathrm{CO}_{2}$ enrichment. Agric. Ecosyst. Environ. 64, 65-73.

Manschadi, A.M., Christopher, J., deVoil, P., Hammer, G.L., 2006. The role of root architectural traits in adaptation of wheat to water-limited environments. Funct. Plant Biol. 33, 823-837.

McGrath, J.M., Lobell, D.B., 2013. Reduction of transpiration and altered nutrient allocation contribute to nutrient decline of crops grown in elevated $\mathrm{CO}_{2}$ concentrations. Plant Cell Environ. 36, 697-705.

Mollah, M., Norton, R., Huzzey, J., 2009. Australian grains free-air carbon dioxide enrichment (AGFACE) facility: design and performance. Crop Pasture Sci. 60, 697-707.

Moore, B.D., Cheng, S.-H., Sims, D., Seemann, J.R., 1999. The biochemical and molecular basis for photosynthetic acclimation to elevated $\mathrm{CO}_{2}$. Plant Cell Environ. 22, 567-582.

Morgan, P.B., Bollero, G.A., Nelson, R.L., Dohleman, F.G., Long, S.P., 2005. Smaller than predicted increase in aboveground net primary production and yield of field-grown soybean under fully open-air $\left[\mathrm{CO}_{2}\right]$ elevation. Global Change Biol. 11, 1856-1865.

Myers, S.S., Zanobetti, A., Klogg, I., Huybers, P., Leakey, A.D.B., Bloom, A.J., Carlisle, E., Dietterich, L.E., Fitzgerald, G., Hasegawa, T., Holbrook, N.M., Nelson, R.L., Ottman, M.J., Raboy, V., Sakai, H., Sartor, K.A., Schwartz, J., Seneweera, S., Tausz, M., Usui, Y., 2014. Increasing $\mathrm{CO}_{2}$ threatens human nutrition. Nature 510, 139-143.

Perry, E.M., Fitzgerald, G.J., Poole, N., Craig, S., Whitlock, A., 2012. NDVI from active optical sensors as a measure of canopy cover and biomass. Int. Arch. Photogramm. XXXIX-B8, 317-319.

R Core Team, 2013. R: A Language and Environment for Statistical Computing. R Foundation for Statistical Computing, Vienna, Austria. http://www.R-project.org/.

Raghuvanshi, R.S., Singh, D.P., 2009. Chapter 25: food preparation and use. In: Erskine, W., Muehlbauer, F.J., Sarker, A., Shama, A. (Eds.), The Lentil: Botany, Production and Uses. CAB International, Cambridge MA USA, pp. 408-424.

Rogers, A., Gibon, Y., Stitt, M., Morgan, P.B., Bernacchi, C.J., Ort, D.R., Long, S.L. 2006. Increased $\mathrm{C}$ availability at elevated carbon dioxide concentration improves $\mathrm{N}$ assimilation in a legume. Plant Cell Environ. 29, 1651-1658.

Rogers, A., Ainsworth, E.A., Leakey, A.D.B., 2009. Will elevated carbon dioxide concentration amplify the benefits of nitrogen fixation in legumes? Plant Physiol. $151,1009-1016$.

Serraj, R., Sinclair, T.R., Allen, L.H., 1998. Soybean nodulation and N2 fixation response to drought under carbon dioxide enrichment. Plant. Cell Environ. 21, 491-500.

Sicher, R., Bunce, J., Matthews, B., 2010. Differing responses to carbon dioxide enrichment by a dwarf and a normal-sized soybean cultivar may depend on sink capacity. Can. J. Plant Sci. 90, 257-264.

Siddique, K.H.M., Erskine, W., Hobson, K., Knights, E.J., Leonforte, A., Khan, T.N., Paull, J.G., Redden, R., Materne, M., 2013. Cool-season grain legume improvement in Australia - use of genetic resources. Crop Pasture Sci. 64, 347-360.

Smith, A.B., Stringer, J.K., Wei, X., Cullis, B.R., 2007. Varietal selection for perennial crops where data relate to multiple harvests from a series of field trials. Euphytica $175,253-266$.

Taub, D.R., Wang, X., 2008. Why are nitrogen concentrations in plant tissues lower under elevated $\mathrm{CO}_{2}$ ? A critical examination of the hypotheses. J. Integr. Plant Biol. 50 (11), 1365-1374.

Tausz, M., Tausz-Posch, S., Norton, R.M., Fitzgerald, G.J., Nicolas, M.E., Seneweera, S., 2013. Understanding crop physiology to select breeding targets and improve crop management under increasing atmospheric CO2 concentrations. Environ. Exp. Bot. $88,71-80$

Tausz-Posch, S., Seneweera, S., Norton, R.M., Fitzgerald, G.J., Tausz, M., 2012. Can a wheat cultivar with high transpiration efficiency maintain its yield advantage over a near-isogenic cultivar under elevated $\mathrm{CO}_{2}$ ? Field Crops Res. 133, 160-166.

Tausz-Posch, S., Norton, R.M., Seneweera, S., Fitzgerald, G.J., Tausz, M., 2013. Will intraspecific differences in transpiration efficiency be maintained in a high $\mathrm{CO} 2$ world? A FACE study. Physiol. Plant. 148, 232-245.

Tausz-Posch, S., Dempsey, R.W., Seneweera, S., Norton, R.M., Fitzgerald, G., Tausz, M., 2015. Does a freely tillering wheat cultivar benefit more from elevated $\mathrm{CO}_{2}$ than a restricted tillering cultivar in a water-limited environment? Eur. J. Agron. 64, 21-28.

Whitehead, S.J., Summerfield, R.J., Muehlbauer, F.J., Coyne, C.J., Ellis, R.H., Wheeler, T.R., 2014. Crop improvement and the accumulation and partitioning of biomass and nitrogen in lentil. Crop Sci. 40, 110-120.

Wolfinger, 1996. Heterogeneous variance-covariance structures for repeated measures. Journal of Agric. Biol. Environ. Stat. 1, 362-389.

Ziska, L.H., Bunce, J.A., Caufield, F.A., 2001. Rising atmospheric carbon dioxide and seed yield of soybean genotypes. Crop Sci. 41, 385-391.

Ziska, L.H., Bunce, J.A., Shimono, H., Gealy, D.R., Baker, J.T., Newton, P.C.D., Reynolds, M., Jagadish, K.S.V., Zhu, C., Howden, M., Wilson, L.T., 2012. Food security and climate change: on the potential to adapt global crop production by active selection to rising atmospheric carbon dioxide. Proc. R. Soc. B 279, 4097-4105. 